\title{
Germination of seeds of robust needlegrass
}

\author{
JAMES A. YOUNG*, CHARLIE D. CLEMENTS, AND T. A. JONES
}

Authors are Range Scientists, USDA, Agricultural Research Service, 920 Valley Road, Reno, Nevada 89512 and Research Geneticist, USDA, Agricultural Research Service, Forage and Range Research Laboratory, Utah State University, Logan, Utah 84322-6300.

*E-mail address corresponding author jayoung@scs.unr.edu

\begin{abstract}
Robust needlegrass (Achnatherum robustum [Vasey] Barkw.) is a native perennial that has great promise for use in erosion control, restoration, and ornamental plantings. Seed dormancy can be a problem in developing new native grass cultivars, especially in species of Achnatherum and related genera. Germination response to a wide range of constant and alternating incubation temperatures is also a key parameter in interpreting seedbed ecology of potential planting material. Our purpose was to investigate the germination of robust needlegrass at 55 constant or alternating incubation temperatures from 0 through $40^{\circ} \mathrm{C}$. Seeds of robust needlegrass germinate over a wide range of incubation temperatures with maximum observed germination over $75 \%$. In terms of restoration ecology, this means that in contrast to many related grass species, severe seed dormancy is not a limiting factor in seeding technology. Optimum germination occurred with 15 to $20^{\circ} \mathrm{C}$ warm periods alternating with 0 to $20^{\circ} \mathrm{C}$ cool periods. The only constant temperature to produce optimum germination was $20^{\circ} \mathrm{C}$. The highest germination occurred at what we consider moderate seedbed temperatures, but some germination occurred at 76 to $89 \%$ of the temperature regimes tested.
\end{abstract}

Key Words: seedbed temperatures, optimum germination temperatures, seed ecology

Robust needlegrass (Achnatherum robustum [Vasey] Barkw. is native to the central Rocky Mountains from Wyoming south to Colorado, Arizona, New Mexico and extending into west Texas and adjacent Mexico (Hitchcock 1935, Hickman 1993, Jones et al. 2000). As the name implies, it is a large grass with culms reaching 1 to $1.5 \mathrm{~m}$ in height. It is not a coarse grass, the leaves are fine and the narrow panicles are quite attractive in appearance. Robust needlegrass has not been developed as a forage or restoration species because of its reputation for inducing narcosis in horses and general avoidance by grazing animals (Bailey 1903). Recent research indicates the narcosis and avoidance by herbivores are a function of an endophyte infection (Jones et al. 2000). Endophyte free lines of robust needlegrass have been developed.

Robust needlegrass has several characteristics that make it a desirable native grass to develop for planting on wildland sites. This species is a very productive grass from which large amounts of biomass can be harvested (Jones et al. 2000). The production tends to occur later in the growing season after the herbage of cool season grasses has matured. Trials located in the Great Basin

\section{Resumen}

Robust needlegrass (Achnatherum robustum [Vasey] Barkw.) es una especie perenne nativa que tiene un gran potencial para usarla en el control de erosión y siembras de restauración y ornamentales. La dormancia de la semilla puede ser un problema en desarrollar nuevos cultivares de zacates nativos, especialmente de especies del genero Achnatherum y generos relacionados. La respuesta de la germinación a un amplio rango de temperaturas de incubación constantes y alterante es también un parámetro clave en interpretar la ecología de la cama de siembra de material potencial para plantar. Nuestro propósito fue investigar la germinación de "Robust needlegrass" a 55 temperaturas de incubación constantes y alternantes variando de 0 a $40^{\circ} \mathrm{C}$. Las semillas de "Robust needlegrass germinaron en un amplio rango de temperaturas de incubación, el máximo porcentaje de germinación observado fue arriba de $75 \%$. En términos de ecología de restauración, esto significa que en contraste a muchas especies de zacates relacionadas, una dormancia de semilla severa no es un factor limitante en la tecnología se siembra. La geminación óptima ocurrió con periodos calientes de $\mathbf{1 5}$ a $20^{\circ} \mathrm{C}$ alternando con periodos fríos de 0 a $20^{\circ} \mathrm{C}$. La única temperatura constante en producir una germinación óptima fue la de $20^{\circ}$ C. La mayor germinación ocurrió en lo que nosotros consideramos una temperatura moderada de la cama de siembra, pero algo de germinación ocurrió en 76 a $89 \%$ de los regímenes de temperatura evaluados.

have indicated that robust needlegrass plants are at least as tolerant to salt affected soils as tall wheatgrass (Elytriga elongata [Host.] Nevski) (unpublished research USDA, ARS, Reno, Nev.). Robust needlegrass is an attractive grass that enhances the visual aspect of landscapes where it is adapted.

A necessary step in getting a new native plant species into the seed trade is to understand the germination characteristics. This is necessary because of: 1) the need to understand germination ecology to propagate the species, and 2) for the legal requirement that the Association of Official Seed Analysts must have an approved standard procedure for germination testing before meaningful percentage germination figures can appear on seed lot tags. Germination in relation to incubation temperatures is a first step in this process.

Our purpose was to develop germination temperature profiles for seeds (caryopses) of robust needlegrass using a wide range of constant and alternating incubation temperatures.

Manuscript accepted 4 Aug. 02. 
Table 1. Germination parameters calculated from quadratic response surfaces (Young and Evans 1982).

\begin{tabular}{|c|c|c|}
\hline Calculated parameters & Derivation of parameter & Purpose \\
\hline \multicolumn{3}{|l|}{ Calculated within profile: } \\
\hline Mean germination & Sum divided by 55 & Gross comparison of profiles \\
\hline Percentage of regimes with germination & Number with germination divided by 55 & Indication of breath of germination response \\
\hline Percentage of regimes with optima & $\begin{array}{l}\text { Number of regimes with germination not } \\
\text { less than the maximum observed minus } \\
\text { one half the confidence interval divided } \\
\text { by } 55\end{array}$ & $\begin{array}{l}\text { Provides indication of the breath of temperatures } \\
\text { that support optimum germination }\end{array}$ \\
\hline Mean of optima & $\begin{array}{l}\text { Sum of optima divided by number of } \\
\text { regimes with optima }\end{array}$ & $\begin{array}{l}\text { Provides a measure of potential germination at } \\
\text { at most desirable temperatures }\end{array}$ \\
\hline Maximum germinatio & Highest observed germination & Indication of potential viability \\
\hline \multicolumn{3}{|l|}{$\underline{\text { Calculated among germination profiles }}$} \\
\hline Frequency of optima & $\begin{array}{l}\text { Times a given temperature supports } \\
\text { optimum germination divided by the } \\
\text { total number of test }\end{array}$ & $\begin{array}{l}\text { Provides an estimate of optimum temperatures } \\
\text { for germination with precision }\end{array}$ \\
\hline
\end{tabular}

\section{Materials and Methods}

Seeds of robust needlegrass were harvested from seed increase fields located at Richland, Utah in 1998 and 1999. Seed was also harvested in 1999 from a stand growing on a saline/alkaline soil near Reno, Nev. (Lat. 39 $32^{\prime}$ Long. 1190 48'). These plants originated from seed harvested at Richland, Utah in 1998 (Lat. 41 ${ }^{\circ}$ 54' Long. $\left.111^{\circ} 50^{\prime}\right)$. This seed was collected from plants that flowered their seedling year.

In all experiments 4 replications of 25 seeds each were used in a randomized block design. Seeds were placed on top of non-toxic commercial germination paper in closed Petri dishes and kept wet with tap water. Germination trials were conducted in the dark with only incidental fluorescent light received during initial wetting and germination counts. Except for the most extremely light sensitive seeds this exposure would not be sufficient to over come dormancy induced by a light quality requirement. Robust needlegrass seeds are adapted for self burial, suggest- ing germination occurs in the dark. Seeds were considered germinated when the radical emerged $5 \mathrm{~mm}$. Germination counts were made after 1, 2, and 4 weeks incubation. Constant incubation temperatures were 0,2 and $5^{\circ} \mathrm{C}$ and at 5 degree increments through $40^{\circ} \mathrm{C}$. In addition, alternating regimes included 16 hours at each constant temperature, plus 8 hours at each possible higher temperature per 24 hours. For example, $35^{\circ} \mathrm{C}$ alternated with $40^{\circ} \mathrm{C}$ only, while $0 \mathrm{C}$ alternated with $2,5,10,15,20$, $25,30,35$, and $40^{\circ} \mathrm{C}$. This made a total of 55 constant and alternating temperature regimes (Young and Evans 1982).

The germination response of robust needlegrass seeds was compared using the seedbed temperature definitions (Young and Evans 1982):

a. Very cold: $0 / 0$ (constant $\left.0^{\circ} \mathrm{C}\right), 0 / 2\left(0^{\circ}\right.$ $\mathrm{C}$ for 16 hours and $2^{\circ} \mathrm{C}$ for 8 hours in each 24 hours period), $0 / 5$ and $2 / 2^{\circ} \mathrm{C}$.

b. Cold: $0 / 10,0 / 15,2 / 5,2 / 10,2 / 15,5 / 5$, and $5 / 10^{\circ} \mathrm{C}$.

c. Cold fluctuating: $0 / 20$ through $0 / 40^{\circ} \mathrm{C}$ and $2 / 20$ through $2 / 40^{\circ} \mathrm{C}$. d. Fluctuating: $5 / 30$ through $5 / 40^{\circ} \mathrm{C}$, $10 / 35,10 / 40$, and $15 / 40^{\circ} \mathrm{C}$.

e. Moderate: $5 / 15$ through $5 / 25,10 / 10$ through $10 / 30^{\circ} \mathrm{C}, 15 / 15$ through $15 / 35^{\circ} \mathrm{C}, 20 / 20$ through $30 / 35^{\circ} \mathrm{C}$, and $25 / 35^{\circ} \mathrm{C}$.

f. Warm: $20 / 40,25 / 35$, and $25 / 40^{\circ} \mathrm{C}$, $30 / 30$ through $30 / 40^{\circ} \mathrm{C}, 35 / 35,35 / 40$, and $40 / 40^{\circ} \mathrm{C}$.

These categories of seedbed temperatures reflect germination environments of field seedbeds based on several years of monitoring in the Great Basin (Evans et al. 1970; Evans and Young 1970, 1972).

Data from each base temperature and its alternating temperature regimes were used to generate a quadratic response surface with estimated means and confidence intervals at the $1 \%$ level of probability (Young et al. 1980, Evans et al. 1982). This statistical procedure was designed for analysis and separation of means when dealing with a continuous variable, in this case incubation temperature. The response surfaces provide continuous statistically precise estimates of germination within

Table 2. Quadratic response surface with estimated percentage germination and confidence interval $(P>0.01)$ for seeds of robust needlegrass incubated at 55 constant or alternating temperatures. Seed produced at Richland, Utah in 1998 . $^{1}$

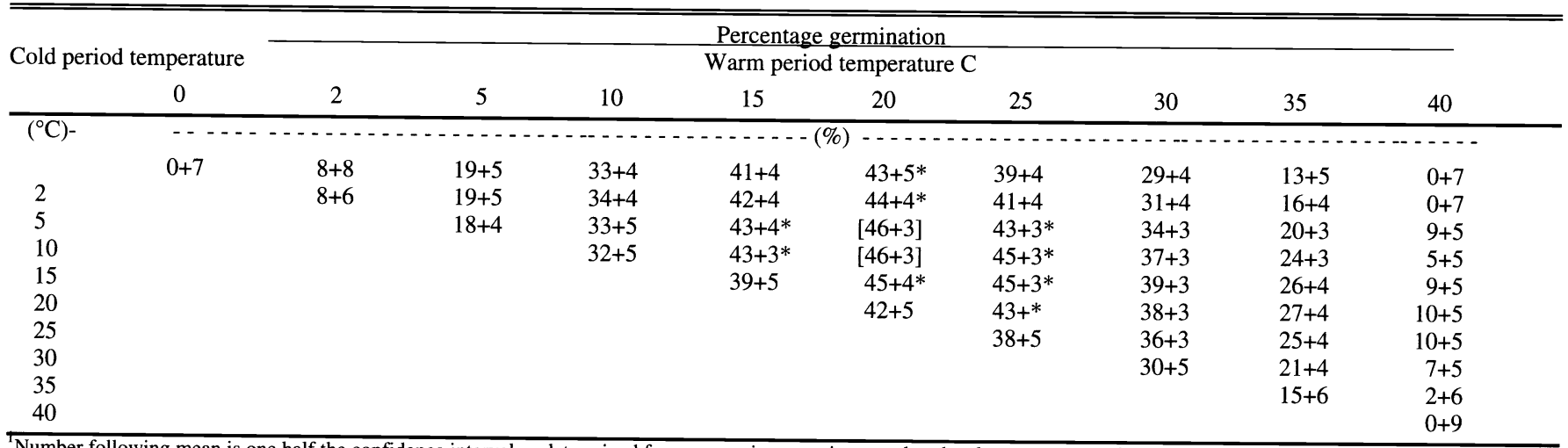

Number following mean is one half the confidence interval as determined from regression equations used to develop response surface (Palmquist et al. 1987). The maximum calculated germination is enclosed by brackets. * indicates means not lower than the maximum germination minus one half of its confidence interval, our definition of optimum germination. 
Table 3. Quadratic response surface with estimated percentage germination and confidence interval $(P>0.01)$ for seeds of robust needlegrass incubated at 55 constant or alternating temperatures. Seed produced at Richland, Utah in $1999 .{ }^{1}$

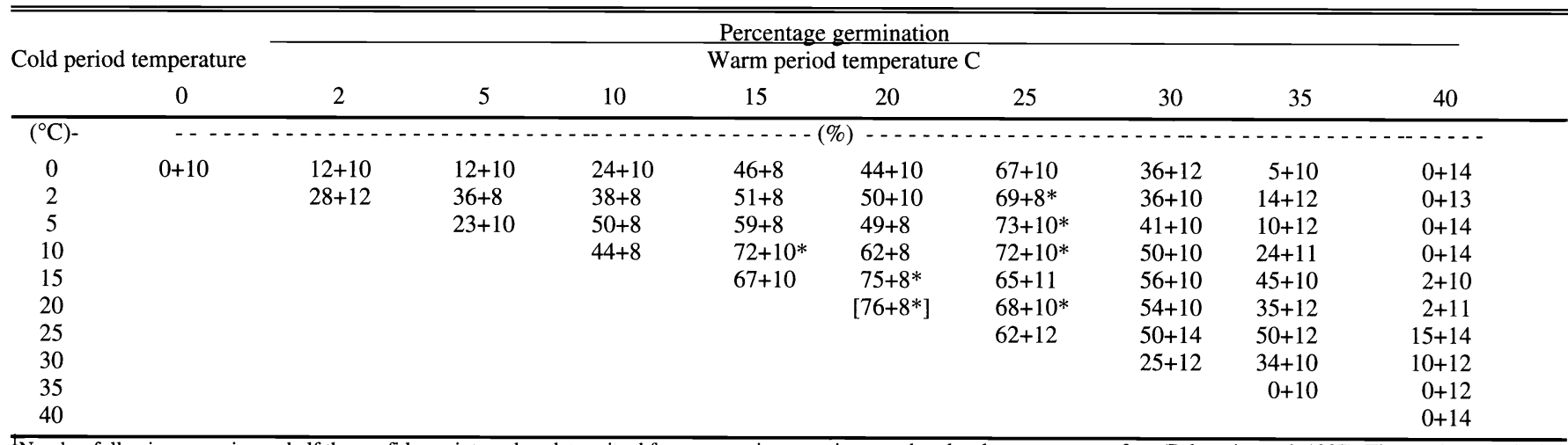

Number following mean is one half the confidence interval as determined from regression equations used to develop response surface (Palmquist et al. 1987). The maximum calculated germination is enclosed by brackets. * indicates means not lower than the maximum germination minus one half of its confidence interval, our definition of optimum germination.

the range of incubation temperatures tested. A number of germination parameters were calculated from the quadratic response surfaces (Table 1) (Young and Evans 1982).

\section{Results and Discussion}

Several related grasses in the needlegrass tribe are notorious for having highly dormant seeds. For some species, such as Indian ricegrass (Achnatherum hymenoides [Roemer \& Schultes] Barkworth), the dormancy may be more of a factor in the laboratory than a hindrance to seedling establishment in the field (Blank and Young 1992, Young et al. 1994). Needle and threadgrass (Hesperostipa comata [Trin. \& Rupr.] Barkworth) obviously recruits seedlings spontaneously in the field, but the seeds are very dormant in the laboratory or most artificial field plantings. Both Columbia needlegrass (Achnatherum lem- momii [Vassey] Barkworth) and desert needlegrass (A. speciosum [Trin. \& Rupr.] Barkworth) produce seeds with limited or no dormancy (Young and Evans 1980, Young et al. 1990). Fortunately, the seeds of robust needlegrass germinate with little evidence of dormancy.

The seeds of robust needlegrass will germinate at a wide range of constant and alternating temperatures (Tables 2, 3, and 4). For seeds harvested from the seed increase fields at Richland, Utah, there were slight differences in germination between years of production. The seeds produced at Reno, Nev. were unique in that they were collected from a stand seeded the previous fall with seeds from the 1998 Richland, Utah increase fields. These Nevada seedlings were growing without supplemental irrigation on a salt affected soil at less that 150 mm of annual precipitation.

For the entire 55 temperature regime profile, the 2 accessions of Utah seeds were higher in germination than the
Nevada seed (Table 5). Between 76 and $89 \%$ of the temperature regimes tested supported some germination. This is an important parameter for a native species being planted under wildland seedbed conditions. Soil moisture and temperature conditions that support optimum germination may often be out of phase (either too cold or too warm). When moisture is available, the potential for even limited germination at non-optimum temperatures may be critical.

The maximum germination and mean of the optima germination was down for the seed produced in Utah in 1998 (Table 5). Plants grown from this seed produced seed (Reno, Nev. 1999) with much higher maximum germination and a higher mean of optima germination. For a native grass selection, maximum germination above $75 \%$ is a very reasonable amount, based on our 40 years testing the germination of seeds of wildland species. This level of gemination indicates a moderate to good

Table 4. Quadratic response surface with estimated percentage germination and confidence interval $(P>0.01)$ for seeds of robust needlegrass incubated at 55 constant or alternating temperatures. Seeds collected from first year stand grown at Reno, Nevada from seed produced at Richland, Utah in $1998 .{ }^{1}$

\begin{tabular}{|c|c|c|c|c|c|c|c|c|c|c|}
\hline \multirow{2}{*}{\multicolumn{2}{|c|}{ Cold period temperature }} & \multicolumn{8}{|c|}{ Percentage germination } & \multirow[b]{3}{*}{40} \\
\hline & & \multicolumn{8}{|c|}{ Warm period temperature $\mathrm{C}$} & \\
\hline & 0 & 2 & 5 & 10 & 15 & 20 & 25 & 30 & 35 & \\
\hline$\left({ }^{\circ} \mathrm{C}\right)-$ & $\cdots$ & $\cdots$ & - & $-\cdots$ & $\ldots$ & )$-\ldots$ & $\cdots$ & $-\cdots$ & $\cdots$ & $\cdots$ \\
\hline 0 & $0+10$ & $12+10$ & $12+10$ & $24+10$ & $46+8$ & $44+10$ & $67+10$ & $36+12$ & $5+10$ & $0+14$ \\
\hline 0 & $0+8$ & $0+7$ & $0+7$ & $5+4$ & $14+3$ & $25+3$ & $30+6$ & $15+9$ & $6+4$ & $0+7$ \\
\hline 2 & & $0+6$ & $2+7$ & $8+5$ & $12+7$ & $25+4$ & $32+7$ & $15+7$ & $7+7$ & $0+6$ \\
\hline 5 & & & $3+3$ & $10+8$ & $15+8$ & $28+8$ & $35+8$ & $17+8$ & $7+6$ & $0+4$ \\
\hline 10 & & & & $15+6$ & $25+6$ & $32+6$ & $45+4$ & $18+4$ & $8+6$ & $0+6$ \\
\hline 15 & & & & & $40+7$ & {$[78+10]$} & $68+9 *$ & $25+8$ & $18+6$ & $2+2$ \\
\hline 20 & & & & & & $70+11^{*}$ & $66+9$ & $32+9$ & $12+9$ & $0+4$ \\
\hline 25 & & & & & & & $60+9$ & $30+8$ & $8+9$ & $0+6$ \\
\hline 30 & & & & & & & & $3+4$ & $2+5$ & $0+9$ \\
\hline 35 & & & & & & & & & $0+8$ & $0+10$ \\
\hline 40 & & & & & 0 & & & & & $0+10$ \\
\hline
\end{tabular}

${ }^{1}$ Number following mean is one half the confidence interval as determined from regression equations used to develop response surface (Palmquist et al. 1987). The maximum calculated germination is enclosed by brackets. * indicates means not lower than the maximum germination minus one half of its confidence interval, our definition of optimum germination. 
Table 5. Comparison of temperature germination profiles for robust needlegrass seeds. ${ }^{1}$

\begin{tabular}{|c|c|c|c|}
\hline \multirow{2}{*}{$\begin{array}{l}\text { Germination } \\
\text { parameter }\end{array}$} & \multicolumn{3}{|c|}{ Seed source } \\
\hline & Richland, Utah 1998 & Richland, Utah 1999 & Reno, Nevada \\
\hline $\begin{array}{l}\text { Categories of seedbed } \\
\text { temperature }\end{array}$ & ( & - & $\cdots \cdots$ \\
\hline Very cold & 9 & 13 & 1 \\
\hline Cold & 35 & $52 \mathrm{a}$ & $10 \mathrm{~b}$ \\
\hline Cold fluctuating & 26 & 32 & 16 \\
\hline Fluctuating & 13 & 7 & 4 \\
\hline Warmer & 12 & 15 & 2 \\
\hline Moderate & 38 & 57 & 39 \\
\hline Profile mean & $22 \mathrm{a}$ & $29 a$ & $12 \mathrm{~b}$ \\
\hline $\begin{array}{l}\text { Temperature regimes with } \\
\text { some germination }\end{array}$ & $89 a$ & $85 \mathrm{a}$ & $76 b$ \\
\hline Maximum germination & $46 \mathrm{~b}$ & $76 \mathrm{a}$ & $78 \mathrm{a}$ \\
\hline Mean of optima & $44 \mathrm{~b}$ & $72 \mathrm{a}$ & $72 \mathrm{a}$ \\
\hline $\begin{array}{l}\text { Temperature regimes with } \\
\text { optimum germination }\end{array}$ & 18 & 11 & 6 \\
\hline
\end{tabular}

${ }^{\mathrm{T}}$ Means within rows followed by the same letter are not significantly different at the 0.05 level of probability as determined by Duncan' Multiple Range test. No letters indicates no significant differences.

level of viability. Perhaps, viability is higher and germination can be further enhanced, but it not so low as to inhibit commercial seed production and marketing.

At very cold categories of seedbed temperatures there was very limited germination of robust needlegrass seeds (Table 5). These temperatures would correspond to seedbeds that froze at night and slightly thawed during the day. Germination increased at cold seedbed temperatures. Robust needlegrass seeds are not highly adapted to germination at cold fluctuating or fluctuating temperature regimes. This is important because it indicates it is not obligatory to plant the caryopses very shallow in seedbeds where such temperature fluctuations can occur. Robust needlegrass seeds are most adapted to germination at moderate seedbed temperatures.

Only one incubation temperature, $15 / 20$ $\mathrm{C}\left(15^{\circ} \mathrm{C}\right.$ for 16 hours and $20^{\circ} \mathrm{C}$ for 8 hours in each 24 hour period) always supported optimum germination (Table 6). Optimum regimes for germination were confined to 15,20 , or $25^{\circ} \mathrm{C}$ warm period temperatures alternating with 5 to $15^{\circ} \mathrm{C}$ cold period temperatures. Only $20^{\circ} \mathrm{C}$ warm period temperatures supported optimum germination when alternating with 0 or $2^{\circ} \mathrm{C}$ cold period temperatures. The only constant incubation temperature that supported optimum germination was $20^{\circ} \mathrm{C}$. If you wish to conduct laboratory test of the germination of seeds of robust needlegrass, the obvious choice for incubation temperature would be $15 / 20^{\circ} \mathrm{C}$. If you do not have incubators that allow for alternating temperature regimes, an constant incubation temperature of $20^{\circ} \mathrm{C}$ should be used. Seeds of robust needlegrass have limited if any dormancy and moderate to good viability as indicated by the maximum germination obtained.

\section{Literature Cited}

Bailey, V. 1903. Sleepy grass and its effect on horses. Sci. 17:576-581.
Blank, R.R. and J.A. Young. 1992. Influence of matric potential and substrate characteristics on germination of Nezpar Indian ricegrass. J. Range Manage. 45:358-362.

Evans, R.A. and J.A. Young. 1970. Plant litter and establishment of alien annual species in rangeland communities. Weed Sci. 18:697-703.

Evans, R.A. and J.A. Young. 1972. Microsite requirements for establishment of alien annual species in rangeland communities. Weed Sci. 20:350-356.

Evans, R.A., D.A. Easi, D.N. Book, and J.A. Young. 1982. Quadratic response surface analysis of seed germination trials. Weed Sci. 30:411-416.

Evans, R.A., H.R. Holbo, R.E. Eckert, Jr., and J.A. Young. 1970. Functional environment of downy brome communities in relation to weed control and revegetation. Weed Sci 18:154-162.

Hickman, J.C.(ed.).1993. The Jepson Manual. Univer. California Press, Berkeley, Calif.

Hitchcock, A S. 1935. Manual of grasses of the United States. Misc. Publ. 200, Washington, D. C.

Jones, T.A., M. H. Ralphs, D.R. Gardner, and N.J. Chatterton. 2000. Cattle prefer endophyte-free robust needlegrass. J. Range Manage. 53:427-431.

Palmquist, D.E., R.A. Evans, and J.A. Young. 1987. Comparative analysis of temperature response surfaces. pp. 97-103 In G.W. Frasier and R. A. Evans (eds.) Seed and Seedbed Ecology of Rangeland Plants. USDA, Agr. Res. Ser., Washington, D. C.

Young, J.A. and R.A. Evans. 1980. Germination of desert needlegrass. J. Seed Tech. 5:40-46.

Young, J.A. and R.A. Evans. 1982. Temperature profiles for germination of cool season grasses. ARR-W-72, USDA, ARS, Oakland, Calif.

Young, J.A., F.L. Emmerich, and B. Patten. 1990. Germination of Columbia needlegrass. J. Seed Tech. 14:225-229.

Young, J.A., R.R. Blank, W.S. Longland, and D.E. Palmquist. 1994. Seeding Indian ricegrass in arid environments in the Great Basin. J. Range Manage. 47:2-7.

Young, J.A., B.L. Kay, H. George, and R.A. Evans. 1980. Germination of three species of Atriplex. Agron. J. 72:705-709.

Table 6. Frequency that temperature regimes supported optimum germination of seeds of robust needlegrass. This provides an estimate of the temperature regimes that most frequently support optimum germination.

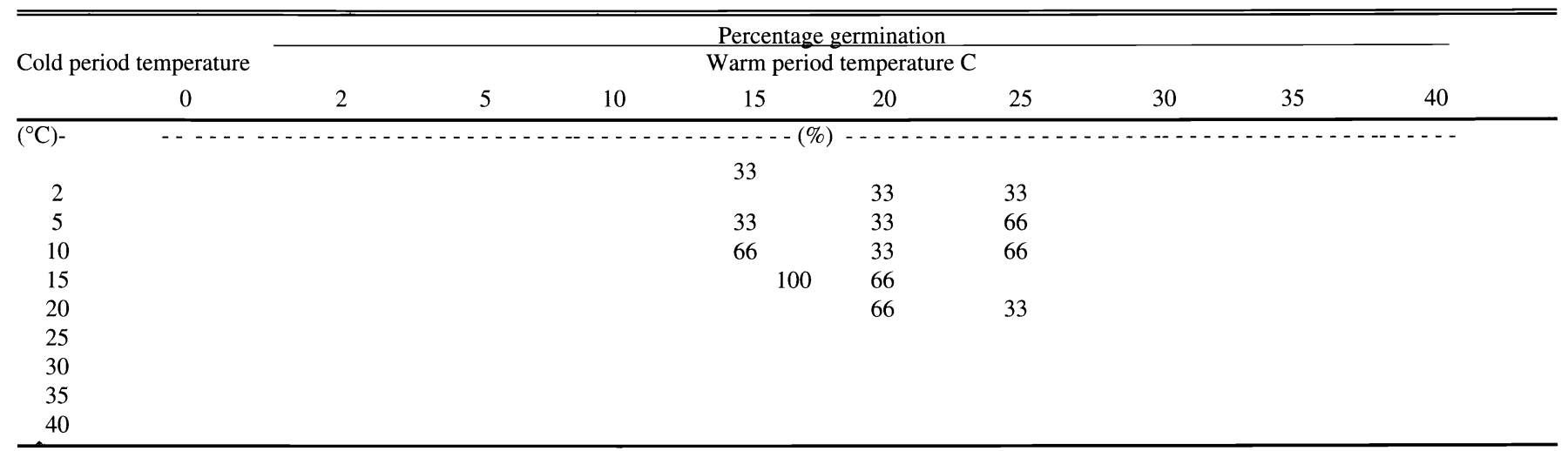

